\title{
VII KONFERENCJA HISTORYKÓW PRAWA OBSZARU MORZA BALTYCKIEGO W KILONII
}

W dniach 3-5 maja 2012 r. w niemieckim Szlezwiku odbyło się kolejne spotkanie cyklicznie organizowanego zjazdu historyków prawa obszaru Morza Bałtyckiego. Tym razem funkcję organizatora przyjął na siebie Wydział Prawa Uniwersytetu Christiana Albrechta w Kilonii, reprezentowany przez przedstawiciela młodszego pokolenia niemieckich historyków prawa, prof. Franka L. Schäfera.

Tematem przewodnim konferencji były sądownictwo i ustrój wymiaru sprawiedliwości, zaś na obrady złożyło się sześć sesji plenarnych. W pierwszym dniu uczestnicy wyshuchali wystapień Aleksandra Rogatschewskiego (Sadownictwo wiejskie i świadomość prawna rosyjskiego chlopstwa po zniesieniu poddaństwa $w$ XIX wieku), Sanity Osipowej (Notariat na tle ustroju sadownictwa na Lotwie w końcu XIX i I pol. XX wie$k u$ ), a także młodych adeptów historii prawa, reprezentujących Estonię (Andres Andresen) i Litwę (Rusne Juozapaitiene), badających ustrój sądownictwa wyznaniowego oraz granice jego kompetencji w prowincjach nadbałtyckich i Wielkim Księstwie Litewskim.

W kolejnej sesji głos zabrali Marju Luts-Sootak (Ustrój sqdownictwa i sqdownictwo $w$ Estonii podczas szwedzkiej okupacji $w$ XVII wieku), Nils Jörn (Sadownictwo w szwedzkich lennach Rzeszy podczas Wojny Pótnocnej), Frank Schäfer (Zwyczajowe prawo prywatne w usus modernusfakultetu w Kilonii). Podczas silnie, wyłącznie, ,profesorsko" obsadzonej sesji, poświęconej kwestiom sądownictwa dziewiętnastowiecznego referowali Joachim Rückert (Savigny, sądownictwo i ustrój sądownictwa - na przykładzie dwóch opinii Rady Państwa), Danuta Janicka (Recepcja pruskiego ustroju sqdownictwa na przykladzie Torunia w prowincji zachodniopruskiej), Hans-Georg Knothe (Ustrój sqdownictwa i proces cywilny w Meklemburgii 1806-1879), Werner Schubert (Prawo i ustrój sqdownictwa w Szlezwiku-Holsztynie przed 150 laty), Janis Lazdins (Reforma sqdownictwa z 1889 r. i jej znaczenie dla baltyckich prowincji Rosji i późniejszej Łotwy). Bardzo zróżnicowany charakter miały wystąpienia dotyczące XX wieku. W tej sesji głos zabrali: Anna Tarnowska (Dualizm sqdownictwa administracyjnego w II RP - sqdownictwo w świetle wplywów pruskich i austriackich), Pia Letto-Vanamo (Sadownictwo w Finlandii w XX wieku), Jukka Kekkonen (Administracja sadowa w Finlandii w okresach pokryzysowych - doświadczenia sytuacji powojennych 1918 i 1945), Elena Makarowa (Edukacyjna działalność aparatu sqdownictwa w regionie nowogrodzkim w latach 70. XX wieku) i Tatiana Borisova (Sadownictwo rosyjskie i problem wykladni prawa w późnej Rosji imperialnej i wczesnej radzieckiej). Konferencję zamknęło wystapienie Ditleva Tamma (Sqdownictwo najwyższe w obszarze Morza Baltyckiego - 350 lat Sqdu Najwyższego w Danii).

Spotkania historyków prawa Morza Bałtyckiego od pierwszej konferencji cechuje wysoki poziom naukowy, chociaż uczestnicy zawsze reprezentują różne wiekowo generacje badaczy. Jest to szczególne forum, gdzie młodzi mogą się uczyć od mistrzów. Każdemu wystąpieniu, wedle niemieckiej tradycji, towarzyszyła wyczerpująca, nieraz wielojęzyczna dyskusja, obfitująca w prawno-porównawcze komentarze i niejednokrotnie skutkująca przedłużeniem obrad. To zrozumiałe, z uwagi na fakt, że uczestnicy dzielą tradycje historycznoprawne, nieraz sobie bliskie, a czasem przecież tożsame. Wystąpienia odzwierciedlały urozmaicony charakter badań referentów; od kwestii ra- 
czej analitycznych (referaty S. Osipowej, F. Schäfera), po bardzo syntetyczne, sygnalizujące zaledwie złożoność problemu (abstrakty prof. Letto-Vanamo, T. Borisovej). Niektóre zapowiadały duże przedsięwzięcia badawcze, jak informacja prof. Tamma na temat projektu poświęconego komparatystycznemu ujęciu charakteru sądów najwyższych wybranych krajów świata i towarzyszącej ich działalności kulturze prawnej.

Część obrad miała miejsce w należącej do Fundacji Otto-Bagge-Kolleg, typowej dla wiejskiej architektury Szlezwiku chacie, położonej uroczo nad brzegiem Bałtyku w niewielkiej wsi Sehlendorf. Uczestnicy mieli także okazję obradować w salach Sądu Okreggowego oraz Archiwum Krajowego w Szlezwiku-Holsztynie. Ostatni dzień konferencji zorganizowany został w Lubece - obradom w Sali Czerwonej przepięknego, eklektycznego ratusza Wolnego Hanzeatyckiego Miasta Lubeki towarzyszyła możliwość zwiedzania najstarszej części miasta pod fachowym przewodnictwem.

Konferencje Historyków Prawa Obszaru Morza Bałtyckiego mająjuż swoją historię; organizatorami kolejnych spotkań były między innymi Helsinki, Greifswald, wspólnie Tartu i Ryga. Kolejne spotkanie zaplanowane jest wyjątkowo na rok 2015. Być może jego gospodarzem będzie Wydział Prawa Uniwersytetu Mikołaja Kopernika w Toruniu, co umożliwi szerszą reprezentację polskiego środowiska historyków prawa.

ANNA TARNOWSKA (Toruń)

\section{MIĘDZYNARODOWE SYMPOZJUM POŚWIECCONE DZIEJOM BIUROKRACJI W EUROPIE (TORUŃ-WLOCLAWEK, 21-24 CZERWCA 2012 ROKU)}

W dniach 21-24 czerwca 2012 r. odbyło się V Międzynarodowe Sympozjum poświęcone dziejom biurokracji w Europie Środkowo-Wschodniej, zorganizowane przez Wydział Prawa i Administracji Uniwersytetu Mikołaja Kopernika, Państwową Wyższą Szkołę Zawodową we Włocławku i Wydział Humanistyczny Uniwersytetu Marii Curie-Skłodowskiej w Lublinie. Organizacja Sympozjum spoczywała w rękach Komitetu Organizacyjnego, do którego wchodzili: dr hab. prof. UMK Zbigniew Naworski jako przewodniczący, dr hab. Andrzej Gaca prof. UMK jako wiceprzewodniczący, dr hab. Waldemar Chorążyczewski (UMK), dr Artur Górak (UMCS) jako sekretarz i dr Dariusz Magier (Archiwum Państwowe w Lublinie). W Sympozjum uczestniczyło 100 uczonych z zagranicy (32 Rosjan, Ukraińcy, Gruzini) oraz 58 uczonych reprezentujących uczelnie polskie, badacze z filii Instytutu Pamięci Narodowej i innych placówek naukowych w kraju. W czasie Sympozjum, którego obrady toczyły się nie tylko w Toruniu, ale i we Włocławku, wygłoszono 76 referatów na posiedzeniach plenarnych i sekcyjnych. Materiały Sympozjum zostaną wydane drukiem w roku 2013. 